\title{
講座 第5回
}

\section{マルチメディアコンテンツフォーマットの実際}

〜放送・通信サービスを実現させた各種フォーマット〜

\section{BMLコーディングの基礎}

\section{1.まえがき}

デジタル放送の特徵の一つであるデータ放送とは, 広義 には，放送電波に映像・音声以外のデータを同時に含めて 送るサービスである. 主なデータ放送サービスとしては下 記の種類がある.

(1) 電子番組ガイド (EPG)：番組表, 番組案内, 視聴・ 録画予約など

(2) 字幕スーパー：訳語字幕, 難聴者保護

(3) 文字スーパー : 気象, 地震, 報道速報など

（4）マルチメディアデータサービス：番組補完情報 (スポ ーツ番組，公営競技など), 独立した情報 (ニュース, 天気，交通情報など), 視聴者参加 (ショッピング, アンケートなど）

上記の中で，マルチメディアデータサービスを実現する 符号化方式が, 今回紹介するBML (Broadcast Markup Language) である. BMLは，XMLベースのマルチメディ ア符号化方式として, ARIB (電波産業会) で制定され, 前 回までに解説のあったXML，XHTML，CSS等をべースに， マルチメディアデータサービスの要求条件を満たす方式で ある。

本稿では, BMLの基本的な構成要素について, 地上デジ タル放送の運用を中心に解説する. なお, BMLには, 地上 デジタルのワンセグ放送向けのプロファイル (ARIB TRB14で規定されたCプロファイル) があるが，これは次回の 講座にて解説される予定である.

\section{BMLの全体像}

BMLを理解する上でまず，BML方式が策定されるにあた って，考虑された要求条件について説明する.

(1) 万人向けのサービスの実現

(a)すべてのデジタルテレビ受信機にデータ放送受信 機能が装備可能なこと

(b)リモコンによる簡単な操作ができること

\section{$\dagger$ 松下電器産業株式会社}

"Multimedia Content Formats in Depth; How Do They Make Interactive Broadcast/Communication Services Possible? (5); The Basis of BML" by Tatsuya Shimoji (Matsushita Electric Industrial Co., Ltd., Osaka) (c) 低価格で受信機を提供できること

(2) 提示の一意性

(a) 全受信機でコンテンツ表示が同じであること

(3) インターネットとの整合性

(a) 放送通信連携サービスの実現ができること

(b) データ放送のコンテンツはインターネット向けに 再利用可能であること

(4) 放送サービスへの拡張機能

(a) 放送波のデータのみでインタラクティブ機能が実 現できること

（b）映像音声と同期したデータ表示が可能なこと

(c) 放送局からのメッセージングが可能であること

（d）コンテンツに関連した情報を受信機に記憶してお く機能を有すること

(e) データ放送からの番組予約・録画予約等

これらの要求条件を満たすために，BMLは以下の枠組み を基本としている.

（1）インターネットとの整合性および拡張性を考慮し, タグセットはXHTML1.0をべースとする.

(2) 提示の一意性を担保するためレイアウト指定手段と してCSS (Cascading Style Sheet) 2を活用する.

(3) 片方向の放送波でインタラクティブ機能を実現する ためにDSM-CCデータカルーセル方式を採用する．さ らに放送局からのメッセージング機能として汎用イ ベントメッセージ方式を用いる.

（4）プログラム機能としてECMAScriptを使用する. 番組 予約や情報の記録制御等の放送特有の機能要件を実 演するために，放送用拡張関数を新たに定義する. 以下で，BMLのそれぞれの構成要素について説明する.

\section{BMLの構成要素}

\section{1 要素・属性}

BMLは, XHTML1.0で定義された要素・属性をベースと する。 その上で, 放送用の拡張機能が定義されている.

\section{(1) 割り达み事象制御}

放送波の同報性を生かして，あるタイミングで一斉に受 信機の表示を切替える，あるいは，伝送路上のデータ更新 をトリガに動作を切替える，というイベント処理を可能と 


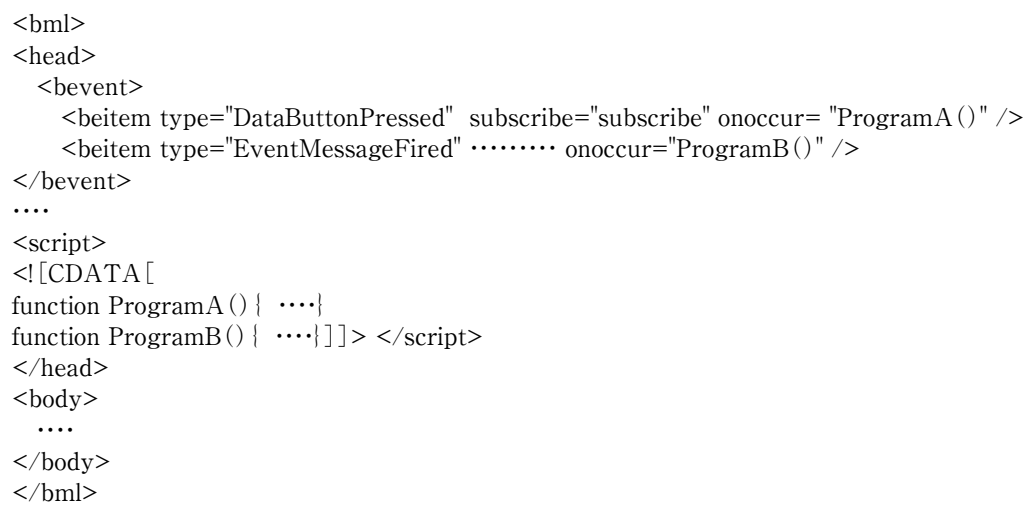

図1＼cjkstart割り込み事象の記述例

表 1 主な割り込み事象の種類

\begin{tabular}{|l|l|}
\hline \multicolumn{1}{|c|}{ 割り込み事象のtype } & \multicolumn{1}{c|}{ 内 容 } \\
\hline \hline EventMessageFired & $\begin{array}{l}\text { イベントメッセージとして伝送される局か } \\
\text { らのメッセージの発生を通知 }\end{array}$ \\
\hline ModuleUpdated & $\begin{array}{l}\text { 特定のモジュール (データカルーセル方式 } \\
\text { で伝送されるデータの1単位)の内容が更新 } \\
\text { されたことを通知 }\end{array}$ \\
\hline ModuleLocked & $\begin{array}{l}\text { 特定のモジュールが受信機のメモリーに固 } \\
\text { 定記憶されたことを通知 }\end{array}$ \\
\hline DatabuttenPressed & $\begin{array}{l}\text { データ放送への切替え(現在の運用では「d」 } \\
\text { ボタン」)が押されたことを通知 }\end{array}$ \\
\hline TimerFired & 指定したタイミングでのタイマ発火を通知 \\
\hline MainAudiostreamChanged & メインの音声の選択切替えが生じた \\
\hline
\end{tabular}

するための機能である. 具体的にはbevent要素, beitem要 素を用いて, 割り込み事象と事象発生時の手続き（プログ ラム)の対応づけを行う（図1）.

また，表1に，BMLで定義された主な割り込み事象の種 類を示す.

（2）remain属性

データ放送では，BML文書を表示する際，テレビ音声を 流し，テレビ映像は縮小して同時表示するのが一般的であ る.このとき, BML文書が切替わっても, 映像・音声を途 切れずに継続再生させる必要がある。 そのため, 映像・音 声に対応するobject要素にremain属性が指定されている場 合には，オブジェクトを遷移先のBML文書に継続すること と規定されている.

（3）ストリーム再生制御のための拡張属性

映像・音声の再生を制御するために属性が追加された。

(a) streamstatus : paly, stop, pause

（b）streamposition：ストリームの時間的な位置指定

(c) streamlooping: 繰り返し再生回数指定 など.

以上, 三つの拡張機能について説明した。 なお，地上デ ジタル放送の運用では，受信機への実装を考慮し，要素・ 属性の運用は必要最小限のものに絞られている。表2に要 表2＼cjkstart地上デジタル放送で運用される要素

\begin{tabular}{|l|l|}
\hline XHTMLモジュール & \multicolumn{1}{c|}{ 運用される要素 } \\
\hline \hline Structure & body, head, title \\
\hline Text & br, div, p, span \\
\hline HyperText & a \\
\hline Forms & input \\
\hline Object & object \\
\hline Metainformation & meta \\
\hline Scripting & script \\
\hline Stylesheet & style \\
\hline Link & link \\
\hline BML & bml, bevent, beitem \\
\hline & \multicolumn{2}{|l}{}
\end{tabular}

素の運用範囲概要を記す.

\section{2 スタイルシート}

BMLでは，レイアウト指定に用いるCSS2に対しても放 送用の拡張が行われている。

(1) 色指定

受信機リソースの制約を考慮し，フルカラーだけでなく， 256色のインデックスカラーで要素の色を指定可能とする ために，下記の特性を拡張している。

(a) clut特性：BML文書に適用するカラーマップデー 夕を指定

(b) color-index, background-color, outline-color-index : インデックスカラーを用いて要素の色を指定

(2) 文書解像度

$\mathrm{HD}$ 映像・SD映像と組合せて表示する際の画面解像度を 指定するためにresolution特性を定義している.

(3) フォーカス制御

リモコンの上下左右キーによるフォーカス移動をコンテン ツ側で制御するために，以下の特性が拡張定義されている。

(a) nav-index特性：フォーカスが設定される要素のイ ンデックス (番号) を指定

(b) nav-right, nav-left, nav-up, nav-down：それぞれ右， 左，上，下キーが押された際に移動するフォーカ 


\section{講座（第 5 回）}

ス先のインデックスを指定する.

(4) リモコンキーの排他制御

放送受信機の場合, 通常数字キーなどは, 放送チャネル の切替わりに使用される. しかしながら，数字キーの押下 で別のBML文書に遷移したり，入力フィールドに数字を入 れる必要が生じる場合がある。 その際に, 数字キーをチャ ネル切替えに使うのか，BML文書内での制御に使うのかを 制御するために，used-key-list特性が規定されている. used-key-listに“basic”が指定されている場合は，数字キー はチャネル選局に使用され, “numeric-tuning”が設定され た場合には, BMLコンテンツで使用することが可能となる。

\section{3 スクリプト}

ユーザ操作に応じてオブジェクトの色や形を変えたり， ある割り込み事象をトリガに別の画面へ表示を変えるなど の動的な制御を記述するためにBMLではECMAScriptと呼 ばれるスクリプト機能を使用する。

データ放送実現のために要求された種々の機能要件は, スクリプトで実行される放送用拡張関数として規定するこ とにより実現している．表3に主な放送用拡張関数を記す.

\subsection{BML文書サンプル}

図2に，簡単なBML文書の一例を示す，BML文書に三つ のオブジェクト (p要素) があり, リモコンで, フォーカス が切替わるごとに， p要素の文字列の内容を切替える例で あり，

（1）各p要素はスタイルシートにより絶対位置を指定

（2）リモコン動作の動きは，CSS特性で記述

（3）フォーカスが切替わった時の動作をスクリプトで記述 としている.このようにスタイル指定, スクリプト記述を
駆使することにより，ディジタル受信機に適したコンテン ツが可能となる.

\section{5 伝送方式}

(1) データカルーセル方式

BML文書や，BML文書から参照されるモノメディアは， ISO/IEC13818-6 (MPEG2のDSM-CC規格) に準拠したデー

\section{表3 主な放送用拡張関数}

\begin{tabular}{|c|c|}
\hline 放送用拡張関数 & 機 能 \\
\hline EPG関連機能 & 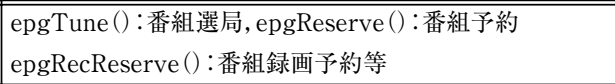 \\
\hline 永続記憶機能 & $\begin{array}{l}\text { 受信機の不揮発領域へのデータ読み書き制御関数 } \\
\text { writePersistentArray ()/ readPersistentAArray () } \\
\text { ゲームのボイントや番組関連データを受信機のNVRAM } \\
\text { に保存するために使用 } \\
\text { 地上デジタル放送では, 記憶可能なNVRAMエリアとし } \\
\text { て, 全放送事業者共通エリア, 放送事業者ごと,あるいは } \\
\text { 系列局ごとのエリアが規定されている }\end{array}$ \\
\hline 双方向機能 & TCP/IPを想定した通信機能 \\
\hline 動作制御 & $\begin{array}{l}\text { メモリー管理機能 (lockModuleOnMemory () 等) } \\
\text { 文書再読み达み }(\text { reloadActiveDocument }()) \\
\text { 文書遷移関数 (launchDocument }()) \\
\text { 画面のロック制御 }(\text { lockScreen }() / \text { unlockScreen }()) \text { 等 }\end{array}$ \\
\hline 受信機音声制御 & $\begin{array}{l}\text { 受信機内藏音声の再生 (playRomSound ()) } \\
\text { ボタン押下時の効果音等に使用 }\end{array}$ \\
\hline $\begin{array}{l}\text { ブックマーク制 } \\
\text { 御機能 }\end{array}$ & \begin{tabular}{|l} 
ブックマークの登録·削除等の関数 \\
$($ writeBookmarkArray ()$/$ deleteBookmarkArray () 等)
\end{tabular} \\
\hline 印刷関連 & $\begin{array}{l}\text { データ放送対応プリンタへの印刷指示機能 } \\
\text { printFile }() / \text { printUri () 等 }\end{array}$ \\
\hline その他 & $\begin{array}{l}\text { BML文書間でのデータ共有のための変数 } \\
\text { (Ureg[], Greg[]) }\end{array}$ \\
\hline
\end{tabular}

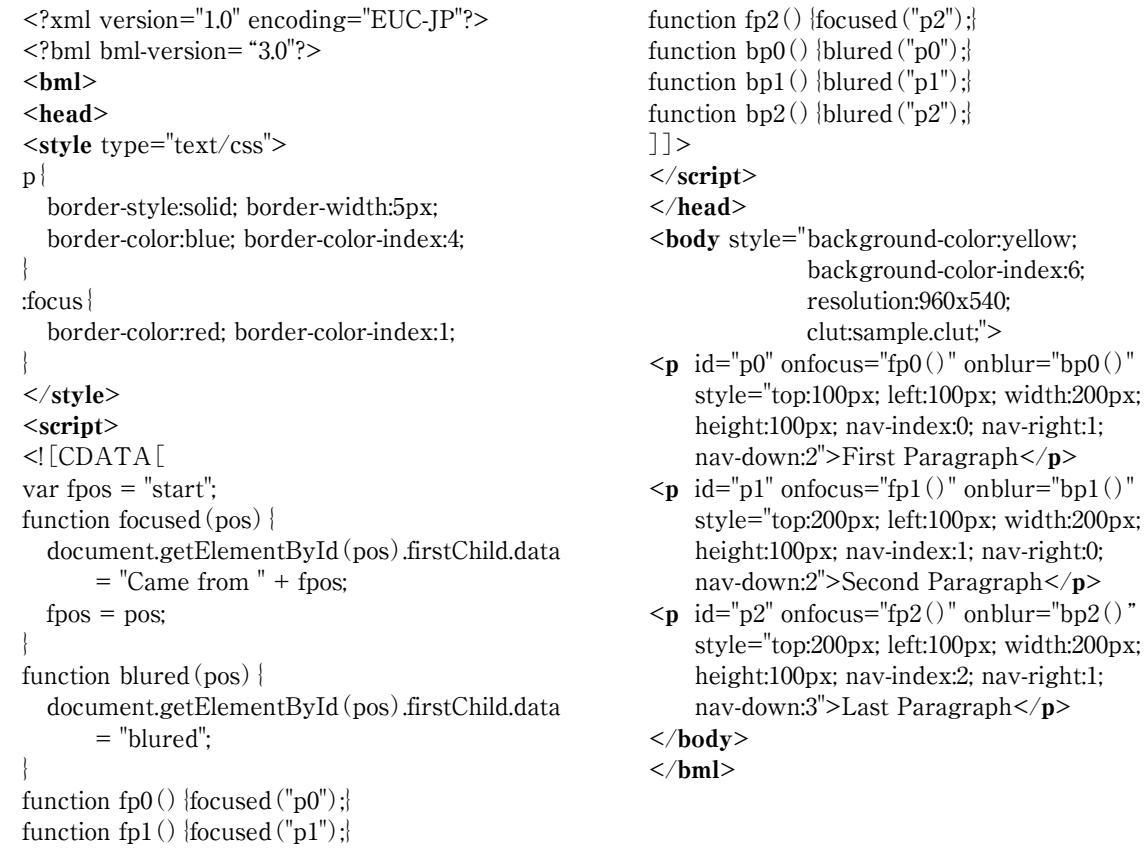


タカルーセル方式と呼ばれる方式で伝送される. カルーセ ル (回転木馬) の名の通り, これらのデータは繰り返し伝送 される. 受信機は必要なデータだけを取り込んで再生する ことにより，片方向の放送波でかつメモリーが限られてい る受信機でもインタラクティブな動作を実現することが可 能となる (図3).

データカルーセルでは, モジュールと呼ばれる単位にデ ータを分割して伝送する. BMLでは一つのモジュールに複 数のファイルが格納できるようにしている(マルチパート). コンテンツ制作側で, 1画面に必要なBML文書, イメージ データを一つのモジュールにマッピングして伝送すれば, 受信機で該当するモジュールを取り込みさえすればBML文 書の再生が可能となる (図4).
(2) イベントメッセージ

局からの指示にしたがって, 受信機上で動作しているコ ンテンツに対して，同期または非同期のメッセージを送る 方式として，イベントメッセージ方式が規定されている (図3). 先述した, bevent, beitem要素を用いて, イベン トメッセージを受信した際の処理を記述することにより， 例えば，番組中のCMに切替わるタイミングで全受信機の 表示を切替えることなどが可能となる.

\section{6 通信機能}

地上デジタル放送からは, ウェブサーバ上のBMLコンテ ンツを提示する機能が運用されている，HTTPを用いて取 得されるコンテンツ (以下，通信コンテンツ) に遷移する場 合には，遷移先として，http: (TLS/SSLを用いたセキュア

ロデータカルーセル：MMサービスのコンテンッ等のファイルを MPEG-2TS上で繰り返し伝送し, 受信機は放送中の任意のタイミングで取得する

口イベントメッセージ：局からの指示に従って，受信機上で動作しているコンテンッに対して，同期または非同期のメッセージを送る メッセージ送出指示

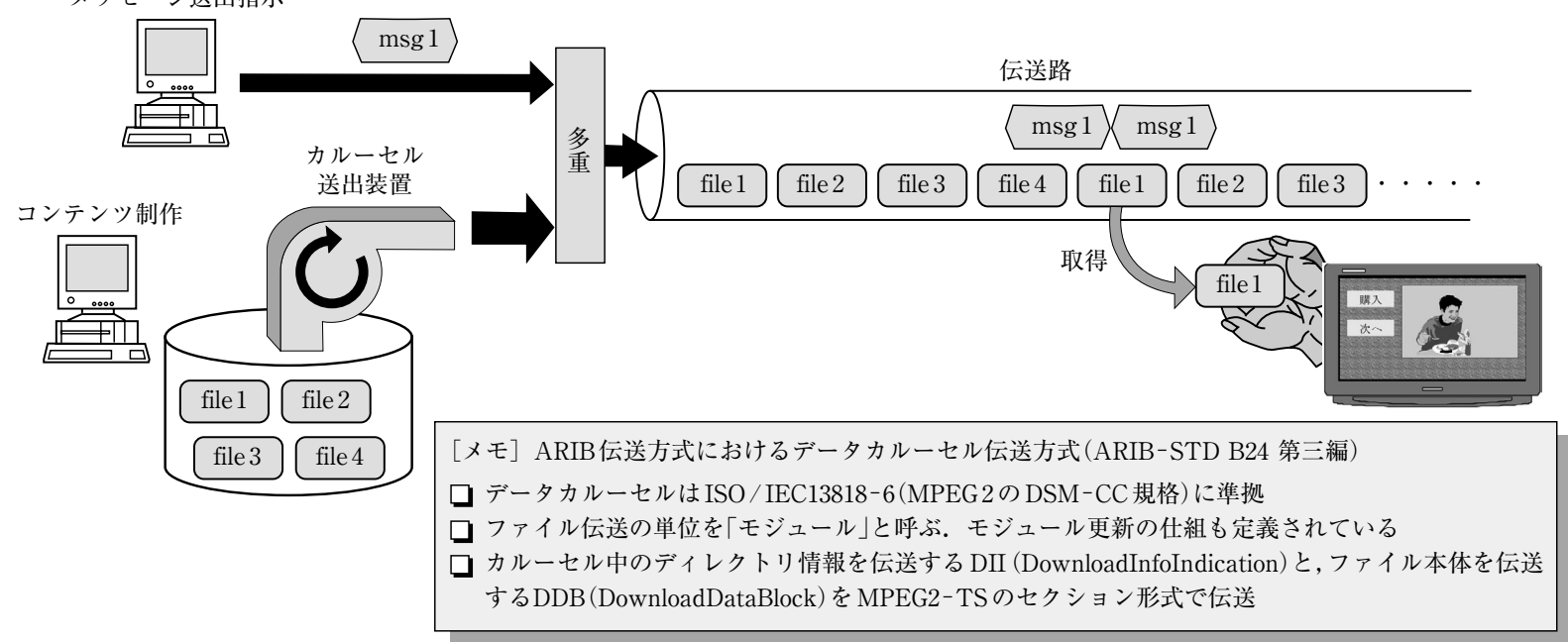

図3 データカルーセルとイベントメッセージ

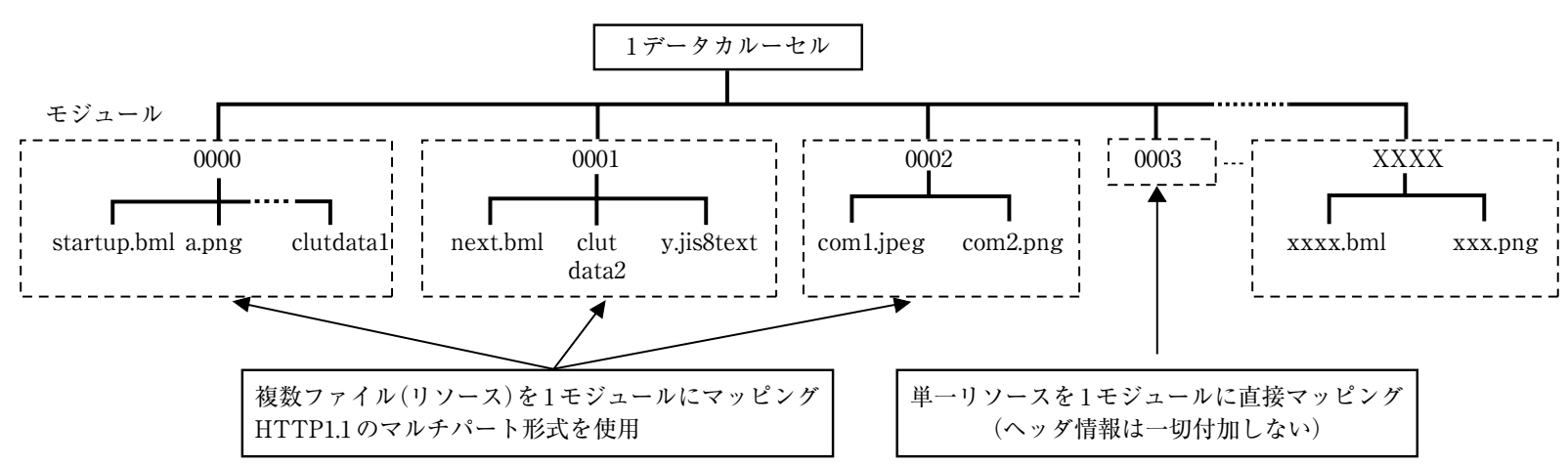

曰URIによるリソースの識別 (名前空間)

arib-dc://<orig_network_id $>$.<transport_stream_id $>$.< service_id $>[.<$ event_id $>] /$

$<$ component_tag $>/<$ moduleName $>/<$ resourceName $>$

（リソースがモジュールに直接マッピングされる場合は，<moduleName>までの指定により識別） 
